\title{
The Politics and Ideology of Non-Restraint: the Case of the Hanwell Asylum
}

\author{
AKIHITO SUZUKI*
}

\section{Introduction}

The non-restraint movement, which aimed at the total abolition of physical or mechanical restraint, was one of the most conspicuous elements of Victorian psychiatry, and its inception in the late 1830s and early 1840s has been studied in detail. Alexander Walk in his article on the Lincoln General Asylum under Edward Parker Charlesworth and Robert Gardiner Hill has uncovered what went on at the birthplace of the movement, and Hunter and Macalpine give a full account of John Conolly's introduction of nonrestraint at the Middlesex County Asylum at Hanwell. ${ }^{1}$ Although these works have thrown valuable light on the struggle at the beginning of the movement, they are too much informed by the opinions of the pioneers themselves and their Victorian followers. Walk and Hunter and Macalpine have uncritically adopted the alienists' view of their own achievement, seeing the movement as the continuation and completion of the progressive and humanitarian effort that Pinel and the York Retreat started around the turn of the century. ${ }^{2}$

A more critical view of non-restraint in a slightly later period has recently been put forward by Nancy Tomes. ${ }^{3}$ Following Andrew Scull's sociological model of psychiatric professionalization, she sees the British insistence on non-restraint in the 1870 s as a tactic to boost the status of public asylum doctors. According to Tomes, non-restraint was orthodox doctrine in Britain, where doctors based at public asylums had a keen sense

*Dr Akihito Suzuki, Research Fellow at the Wellcome Institute for the History of Medicine, 183 Euston Road, London NW1 2BE.

I wish to thank the Wellcome Trust and the Japan Society for the Promotion of Sciences for providing funding to undertake the research upon which this paper is based. W F Bynum, Michael Neve, and Andrew Wear have commented on earlier drafts. Peter Bartlett and Roy Porter have provided invaluable suggestions throughout my research. I am most grateful to them.

1 Alexander Walk, 'Lincoln and non-restraint', Br. J. Psychiatry, 1970, 117: 481-96; John Conolly, The construction and government of lunatic asylums, and hospitals for the insane, London, John Churchill, 1847 , repr. with introduction by Richard Hunter and Ida Macalpine, London, Dawsons of Pall Mall, 1968.
2 Richard Hunter and Ida Macalpine, Three hundred years of psychiatry, London, Oxford University Press, 1963, p. 887; Robert Gardiner Hill, A concise history of the entire abolition of mechanical restraint in the treatment of the insane, London, Longman, Brown, Green, and Longmans, 1857, p. 147; John Conolly, The treatment of the insane without mechanical restraints, London, Smith, Elder, 1856, pp. 18-19.

${ }^{3}$ Nancy Tomes, 'The great restraint controversy: a comparative perspective on Anglo-American psychiatry in the nineteenth century', in W F Bynum, $\mathrm{R}$ Porter, and M Shepherd (eds), The anatomy of madness: essays in the history of psychiatry, vol. 3, The asylum and its psychiatry, London, Tavistock Publications, 1988, pp. 190-225; Andrew Scull, The most solitary of afflictions: madness and society in Britain, 1700-1900, New Haven, Yale University Press, 1993. 


\section{Akihito Suzuki}

of competition with lay reformers and private profit-making doctors. Mechanical restraint was used relatively freely in the United States, where there was little rift between private/public doctors and lay/medical views.

Tomes's model apparently applies to the Anglo-American non-restraint debate in the 1870s. It does not, however, work well for the earliest phase of the movement. The most serious flaw in Tomes's account, shared by those of Walk and Hunter and Macalpine, is that it is almost exclusively concerned with the logic and rhetoric of doctors, as if it had been only doctors who promoted the non-restraint system. The instalment of the system by Conolly in the Hanwell Asylum tells an entirely different story. There the role of the county magistrates of Middlesex was as vital as that of the medical head. Non-restraint there was a part of the overall reform of the structure of asylum management, initiated, planned and executed by the magistrates. The magistrates had good reason to take the rather drastic step of total abolition of mechanical restraint. They were under pressure from the Whig central government, which after the 1832 Reform Act attempted to redefine the relation between central and local authorities, particularly through the introduction of the New Poor Law (1834) and prison inspection (1835). ${ }^{4}$ Non-restraint at the Hanwell Asylum, I will argue, was a political gesture on the part of the magistrates, as well as Conolly's achievement.

Looked at as a movement promoted by lay initiative, non-restraint at Hanwell emerges as having double-edged consequences for Conolly himself and for the emerging psychiatric profession. On the one hand, it certainly gave a humanitarian halo to the medical superintendents of public asylums, and made Conolly a national and international hero. ${ }^{5}$ On the other hand, the spectacular success of non-restraint at Hanwell paradoxically turned out to be very detrimental to the advancement of the psychiatric profession's interests. By his own success in implementing the programme of the lay magistrates, Conolly lost the right to claim that a medical head was the linchpin of an asylum. He made himself a mere replaceable cog in the bureaucratic machine that the asylum now became, and, after five years' medical superintendentship, he found himself replaced by a lay ex-military officer. This outcome, which was disastrous on both a personal and a professional level, was inherent in the system so enthusiastically embraced by Conolly himself.

\section{The Hanwell before Non-Restraint: Clitherow and Ellis}

To assess the magistrates' motives for adopting such an extremist doctrine as the total abolition of mechanical restraint, a brief look at the previous state of affairs is necessary.

\footnotetext{
${ }^{4}$ In the context of my argument, the creation of the government inspectorate of prisons was especially important. Eric J Evans, The forging of the modern state: early industrial Britain 1783-1870, London, Longman, 1983, pp. 285-91; Sidney Webb and Beatrice Webb, English prisons under local government, London, Longmans, Green and Co., 1922 , p. 112. Peter Barlett has proposed a new conceptual model to understand the treatment of lunatics as an integral part of the poor law policy of local and central governments, from which the
}

present paper has benefited very much. Peter Bartlett, 'The Poor Law of Lunacy: the administration of pauper lunatics in mid-nineteenth-century England with special emphasis on Leicestershire and Rutland', PhD thesis, University of London, 1993.

5 Andrew Scull, 'A Victorian alienist: John Conolly, FRCP, DCL (1794-1866)', in W F Bynum, R Porter, and M Shepherd (eds), The anatomy of madness: essays in the history of psychiatry, vol. 1, People and ideas, London, Tavistock Publications, 1985, pp. 103-50, on pp. 122-5. 


\section{The Politics and Ideology of Non-Restraint}

Colonel James Clitherow, a magistrate for the county of Middlesex, had played the most prominent role in the early history of the Hanwell Asylum. From the very beginning of the plan to build it in 1827 , he was at the centre of the project, uninterruptedly serving as the chairman of the committee of magistrates to supervise the institution until his retirement in $1838 .^{6}$

Clitherow's profile was that of a typical benevolent and high-minded country squire. He was a staunch High Church Tory, chairman of the Middlesex Conservative Registration Committee, vice-President of the Lay-Union for the Defence of the Established Church. ${ }^{7}$ His strong personal ties to the court of William IV brought to the asylum the Queen Adelaide Fund, a charitable fund for discharged lunatics, and a knighthood for William Ellis, the asylum's medical superintendent. ${ }^{8}$ When Ellis resigned and the committee elected a new medical head in 1838, Clitherow threw the casting vote against Whig and Unitarian Conolly in favour of James Millingen, an Anglican. ${ }^{9}$

Clitherow's committee does not, however, seem to have meddled in the asylum's dayto-day management, but left it almost entirely to the discretion of Ellis. Ever since its opening in May 1831, Hanwell was, so to speak, a huge household entrusted to Ellis and his wife, who took care of almost all aspects of the institution, medical, financial, administrative, and spiritual. Ellis held the office of treasurer, had power to appoint subordinate officers and attendants, and dispensed moral treatment to the patients. Arranging the employment of the patients was his proud responsibility, while in Bethlem it was not the business of the doctors but of the steward. ${ }^{10}$

This style of management helped to create a distinctive family ambience. Indeed, Ellis encouraged the domestic atmosphere, following the established doctrine of the moral treatment at the York Retreat, which propagated the curative and benign effect of parental care. The role of Lady Ellis as the matron was widely publicized, which invited cynical comments from some quarters, but Harriet Martineau eulogized the Ellises as the loving parents of the inmates. ${ }^{11}$

\footnotetext{
${ }^{6}$ The records of the Hanwell Asylum are kept at the Greater London Record Office (GLRO). One of the earliest meetings in January 1827 was already chaired by Clitherow and on 29 November, he was officially appointed to the post (GLRO MJ/SP/1827/LC/1). See also GLRO MJ/OC/29, p. 219.

${ }^{7}$ For the life of Clitherow see Mary Clitherow, Glimpses of King William IV and Queen Adelaide, London, R. Brimley Johnson, 1902; John Stoddart, A funeral sermon preached on ... the death of James Clitherow, London, J G F \& J Rivington, 1841; obituary in Gentleman's Magazine, 1841, 16: 656.

${ }^{8}$ Clitherow, op. cit., note 7 above, p. 63; William Ellis, $A$ treatise on the nature, symptoms, causes and treatment of insanity, with practical observations on lunatic asylums, London, Samuel Holdsworth, 1838, pp. iii-iv.

9 James Clark, A memoir of John Conolly, M.D., D.C.L., comprising a sketch of the treatment of the insane in Europe and America, London, John Murray, 1869, p. 53. Just after he lost the election, Conolly alluded to the "political and religious
}

prejudice" of magistrates in John Conolly, 'Review of William Ellis, A treatise, Caleb Crowther, Observations on the management of madhouses, et. al.', British and foreign medical Review, 1839, 7: 1-55, pp. 48-9. For Millingen's life, See James Millingen, Mind and matter, illustrated by. considerations on hereditary insanity, London, H Hurst, 1847; The Times, 1842, 14 Oct., $6 \mathrm{f}$.

${ }^{10}$ GLRO MJ/OC/24, pp. 488-9 and 549-50; Harriet Warner Ellis, "Our doctor", memorials of Sir William Ellis, M.D., of Southall Park, Middlesex, London, Seeley, Jackson \& Halliday, [1868], pp. 53 and 15. Bridewell and Bethlem, Court of Governors' MSS Minutes, 26 April 1841, p. 2.

" Ellis, op. cit., note 8 above, pp. 214-15. For favourable and unfavourable comments on Lady Ellis's prominent role in the asylum, see, respectively the review of Ellis's Treatise in Edinburgh medical and surgical Journal, 1838, 50: 242-64, and Conolly, op. cit., note 9 above, p. 50. For Martineau's comment see Warner Ellis, op. cit., note 10 above, pp. 36-7. 


\section{Akihito Suzuki}

Ellis thus reigned over the patients, officers, and attendants as the patriarch of the institution. Small wonder that he behaved as if Hanwell were his institution and as if he had discretionary power over admission, refusing to admit a patient brought by a parish overseer to the gates of the asylum, and shouting, "I am master here and nobody else". Though the cult of domesticity was fairly common in asylums at that time, Ellis's commitment to the ideal was remarkable. When later he set up his own private institution, he singled out its family atmosphere as something unique. ${ }^{12}$

Religious influences were another distinctive feature of Ellis's asylum, probably also encouraged by the example of the Retreat. His biographer informs us that in his youth Ellis had gone through a conversion to Methodism, and the patients at the Wakefield Asylum shed a silent tear with quivering lips when Ellis read daily prayers to them. His annual reports at the Hanwell include numerous references to his piety and his belief in the power of religion to relieve the suffering of lunatics. ${ }^{13} \mathrm{He}$ even expressed an evangelical hope that an asylum should perform the function of a religious school, instructing the pauper lunatics in religion, turning them into an army of missionaries, and through them disseminating "temperance, decorum, and piety" as well as the Gospel. ${ }^{14}$ Although one is tempted to doubt the extent of the success of this endeavour to replicate the Retreat and to create a domestic, personal, and religious atmosphere at an institution which housed 700 inmates, still it seems that Ellis and the Hanwell were regarded as a considerable success. ${ }^{15}$

There was no want of critics, however. The most fervent was Caleb Crowther, a former apothecary at the Wakefield Asylum who published three books attacking Ellis and the magistrates of the West Riding and Middlesex. ${ }^{16}$ Crowther's works seem to have been motivated as much by his personal antagonism towards his former employer as by his own radical criticism of the political and social status quo. Crowther's books contained a remarkably direct attack on the old and nepotistic rule of well-wishing but inefficient country gentlemen. He called for the establishment of a central government board exclusively consisting of medical men, and replacing the magistrates' corrupt rule over county asylums with doctors' professional inspections.

Conolly turned out to be another critic of Ellis's regime. Obviously upset after being defeated by the Hanwell magistrates in his first application for the superintendency, Conolly backed up Crowther's complaints, criticized Ellis's over-concentration on the housekeeping affairs of the asylum, and reminded him of the medical nature of such an

${ }^{12}$ GLRO MJ/OC/26, pp. 224-8 and 262-5; a handbill for Southall Park House, in the Papers of the Society for the Improvement of the Condition of the Insane, the Royal College of Physicians of Edinburgh.

${ }^{13}$ Warner Ellis, op. cit., note 10 above, pp. 4-7, 14-15, and passim; GLRO H1 1/HLL/A7/1, The reports of resident physicians of the County Lunatic Asylum at Hanwell, London, M'Gowan, 1842, pp. 25-6.

${ }^{14}$ Ellis, op. cit., note 8 above, pp. 231-5. For temperance, GLRO H11/HLL/A7/1, pp. 20-1.

\footnotetext{
15 The debate over the Hanwell in the Commons in 1837 suggests its high reputation. See Hansard, 1837, cols. 1486-89.

${ }^{16}$ Caleb Crowther, Observations on the management of mad-houses, illustrated by occurrences in the West Riding and Middlesex Asylums, London, Simpkin, Marshall, 1838; Observations on the management of mad-houses, part the second, London, Simpkin, Marshall, 1841. The third part was published in 1849. A glance into his life is obtained in John D Lorraine, Two sermons, occasioned by the death of Caleb Crowther, n.p., 1849; Edinburgh medical and surgical Journal, 1839, 51: 215-31, p. 231.
} 
institution. ${ }^{17}$ Conolly differed, however, from Crowther in his view of the magistrates. In contrast to Crowther's sweeping and radical denunciation of the role of gentlemanly unpaid magistrates, Conolly made only a mild protest at those who turned down his application, hoping that "among several magistrates he cannot fail to find some men of sense who will support him in all that deserves support". He even preferred to work with magistrates rather than to be inspected by his medical and professional brethren. ${ }^{18}$ Conolly thus managed to limit his criticism of Ellis and the Hanwell Asylum within the status quo of local government, following the moderate Whiggism he typically embraced. ${ }^{19}$

These criticisms from medical figures seem to have been less damaging to Ellis than those from the magistrates who were his employers. Although running a public asylum as a quasi-household was not uncommon, Ellis and the asylum committee were often criticized for the lack of rigour and rational organization in its management. ${ }^{20}$ Beginning in 1835 , the vestry of the parish of St George Hanover Square instigated a series of attacks upon the asylum committee for abusing public money, recommending that the asylum be modelled upon the frugality of workhouses. The question of whether it was proper to appropriate surplus money for enlarging and improving the asylum building was especially controversial. The asylum committee argued that it was within the power of the magistrates to do so; the parish vestry demanded that the money be refunded. ${ }^{21}$

What is more significant is that behind the attacks from the vestry lurked the threat of centralization from the Whig government, with Lord John Russell as the Home Secretary, who once said "the landed gentry are certainly the class in this country most ignorant, prejudiced and narrow-minded". ${ }^{22}$ In the row between the county and the Hanover Square parish vestry, Russell took the side of the vestry, and told the magistrates to consider the problem of the office of treasurer. ${ }^{23}$ In the House of Commons, Russell was behind the motion of Henry Gally Knight, a Whig MP, to establish a committee to inquire into Ellis's slipshod management and incorrect statistics. ${ }^{24}$ Russell's shadow was even present within the magistrates' asylum committee itself. In 1836 Robert MacWilliam, a Whig MP and one of the Middlesex justices and members of the asylum committee, attacked Ellis's personal, discretionary and ill-

\footnotetext{
${ }^{17}$ Conolly's criticism that "the asylum becomes a good boarding-house, a safe prison, a kind of showhouse, but not an hospital, not a place of cure" is quite apposite, for Ellis was satisfied to report that the asylum looked like "a little independent colony, [rather] than ... a sick hospital". Conolly, op. cit. note 9 above, p. 50; GLRO H1 1/HLL/A7/1, p. 30.

${ }^{18}$ Conolly, op. cit., note 9 above, p. 49.

${ }^{19}$ For the political affiliation of Conolly, see Adrian Desmond, The politics of evolution: morphology, medicine, and reform in radical London, University of Chicago Press, 1989, pp. 203-5; Henry Maudsley, 'Memoir of the late John Conolly', Journal of mental Science, 1866, 12: 151-74, pp. 164-7.

${ }^{20}$ See, for example, T O Pritchard's responsibilities in the Northampton General Lunatic Asylum, St Andrews' Hospital, Northampton, MSS
}

minutes relating to the founding of the general lunatic asylum, 2 Jan. 1839; 30 Oct. 1839; 9 July 1840; 30

Dec. 1840; 31 March 1841.

${ }^{21}$ GLRO MJ/OC/27, pp. 252-86 and 349-63; $\mathrm{MJ} / \mathrm{OC} / 28$, pp. $220-42$.

22 Oliver MacDonagh, Early Victorian government 1830-1870, London, Weidenfeld and Nicolson, 1977, p. 165.

23 GLRO MJ/OC/28, p. 221.

${ }^{24}$ Knight was one of the members of the vestry and moved on its behalf. GLRO MJ/OC/28, p. 222; $\mathrm{MJ} / \mathrm{OC} / 29$, pp. 52-3. Ill-prepared and lacking any solid evidence, the motion was rejected at the suggestion of Russell. See Hansard, 1837, cols. 1486-89. For Knight's fervent Whiggism, see Henry Gally Knight, Substance of two speeches delivered at Mansfield \& Retford, London, James Ridgeway, 1833. 


\section{Akihito Suzuki}

defined authority in the asylum and demanded full answers to questions about the matters of finance and administration. This occasioned "some sharp remarks" from Clitherow and other members of the committee, who were obviously displeased at the rather insolent and inspector-like tone of MacWilliam's motion, and it was eventually dropped. ${ }^{25}$ The threat of outside inspection of the asylum and the prospect of humiliation for its governors were none the less looming.

The government and the Middlesex justices confronted each other over many issues. ${ }^{26}$ The newly established inspectorate of prisons exacerbated the confrontation. The inspectors for the Home District, William Crawford and the Rev. Whitworth Russell (Lord John's nephew), were adamant supporters of the "solitary" system, and in their report in 1837 criticized the Coldbath Field House of Correction run by the Middlesex magistrates, which had adopted the rival "silent" system since $1834 .{ }^{27}$ In reply, doctrinaire "silentist" magistrates like Peter Laurie, governor of Bethlem, fiercely attacked the "separate" system by pointing out that solitary confinement had driven the prisoners mad; Charles Augustus Tulk, one of the active members of the county prison committee, stated that they would invent a new system which would combine the advantages of the two. ${ }^{28} \mathrm{G}$ L Chesterton, the governor of the Coldbath Field, complained that "the personal rudeness of Mr Whitworth Russell became unworthily insulting."29 In 1838 , the county confronted the government and the Russells, over both the asylum and the prison.

\section{Rationalising the Asylum: the Magistrates' View}

The response of the core part of the magistrates in this contest with the government shows that they were by no means entrenched traditionalists or the victims of utilitarian centralization. The behavioural pattern of the many active magistrates of Middlesex indicates a modernized gentry ethos and the readiness to jump onto the reform bandwagon or even to outdo the central government reformers. Indeed, my research confirms recent revisionist accounts, especially in the context of the New Poor Law of 1834 , of the role of magistrates as agents of modernization and allies of the reformers. ${ }^{30}$ John Adams, a sergeant-at-law and the chairman of the magistrates from 1836 to 1844 ,

\footnotetext{
${ }^{25}$ GLRO MJ/OC/28, p. 291; The Times, 1836, 2 Sept., 4 b, and 28 Oct., 4 b. See also Robert MacWilliam, Middlesex in Parliament. One thousand pounds annually to be paid out of the county rates. A letter to the rate payers, n.p., 1841, p. 4 , where he attacked the "waste and neglect" at the Hanwell.

${ }^{26}$ The question whether the magistrates or the Home Office had the right to appoint the chairman of the quarter sessions court was particularly important. See The Times, 1836, 14 May, 5 e, and 27 May, 4 a.

27 Sidney and Beatrice Webb, op. cit., note 4 above, pp. 122-5; Sean McConville, $A$ history of English prison administration: vol. I 1750-1877, London, Routledge \& Kegan Paul, 1981. For the conflict between the two systems, see U R Q Henriques, 'The rise and decline of the separate system of prison discipline', Past and Present, 1972, no. 54, 61-93. See also Philip Collins, Dickens and
}

crime, London, Macmillan, 1962; idem, 'The Middlesex magistrate in "David Copperfield", Notes and Queries, 1961, March, 86-91.

${ }_{28}$ The Times, 1838, 23 Feb., 7 a; McConville, op. cit., note 27 above, p. 173; George Laval Chesterton, Peace, war, and adventure: an autobiographical memoir, London, Longman, Brown, Green, and Longmans, 1853, vol. 2, pp. 237-44 and 276.

29 McConville, op. cit., note 27 above, p. 173.

30 Anthony Brundage, The making of the New Poor Law: the politics of inquiry, enactment, and implementation, 1832-1839, London, Hutchinson, 1978; Peter Mandler, 'The making of the New Poor Law redivivus', Past and Present, 1987, no. 117, 131-57; Anthony Brundage, David Eastwood, and Peter Mandler, 'The making of the New Poor Law redivivus: debate and reply', Past and Present, 1990, no. $127,183-201$. 


\section{The Politics and Ideology of Non-Restraint}

played an especially prominent role in guiding them to adopt a strategy of playing a double game in social policy. On the one hand, they criticized the cold-blooded Benthamism of the central government and stressed the benevolent paternalism of local justices. Adams was then known as a protagonist of Blackstonian Englishman's privilege of trial by jury against efficiency-conscious summary jurisdiction, and an opponent of Brougham's central criminal court. ${ }^{31}$ On the other hand, they tried to outshine the government in inspection, rationalization, discipline, and social control. Thus, for instance, Adams's criticism of the summary tribunal of juvenile offenders (immortalized by Dickens in Oliver Twist) conjured up a scandalous picture of children committed to solitary confinement in a government-run prison, and argued that they should be put into a reformatory school instead. This benevolent attitude was, however, accompanied by a stern voice which said that at reformatory school (realized as the Parkhurst Prison for Juvenile Offenders) the children were more effectively disciplined. Adams even argued that not only actual but also possible juvenile offenders should be sent to the school or to the colonies. ${ }^{32}$

The modernized ethos of the magistrates was most visible in their asylum reform. In early 1838 , determined to oppose the government, the magistrates started to manage the asylum themselves, instead of trusting it to the personal and discretionary power of the medical superintendent. Adams and Tulk, who played a vital role in Middlesex prison reform as well, replaced Clitherow as the key figure on the asylum committee. ${ }^{33}$ Adams was on the committee from 1839 to $1844 .{ }^{34}$ Although he was a Tory who in 1837 had stood for the seat of the borough of Warwick, his keen grasp of the changing society and awareness of the necessity for measured reform coexisted with his belief in the traditional idea of the ruling class's responsibility to do good toward the poor ${ }^{35} \mathrm{His}$ professional legal education, skilful use of statistics, social scientific approach to the question of amelioration, and "universal urbanity", as one of his fellow magistrates phrased it, suggest a more dynamic and liberal Toryism than the entrenched "country" one of Colonel Clitherow. ${ }^{36}$

The mental outlook of Tulk was even further from Clitherow's. Tulk was a former Whig MP, a very close friend of Joseph Hume, the radical "People's MP”. He was liberal in his religious views, promoted Catholic emancipation, and was one of the proprietors of the newly established University College London. Moreover, he was a confessed

\footnotetext{
31 John Adams, A letter to Benjamin Hawes, Esq. M.P. and Chairman of the Metropolitan Police Committee, London, J Hachard and Son, 1838, pp. 14-21; idem, Central Criminal Court Jurisdiction. A letter to the Right Hon. J. S. Wortley, M.P., London, W Benning, 1854; MacDonagh, op. cit., note 22 above, p. 164.

32 Adams, op. cit., note 31 above (1838), pp. 14-22 and 35-44; The Times, 1838, 23 Feb., 7 a. Children's Friend Society, Fourth annual report for the year 1834, London, for the Society, 1834, pp. 25-6. Adams was a subscriber to the Society.

${ }^{33}$ In 1839 Clitherow retired from the chair on the pretext of "sudden illness". Although there is no tangible evidence, one is tempted to suspect some conflict, especially when one learns that Clitherow
}

continued to hold another office till 1841. GLRO $\mathrm{MJ} / \mathrm{OC} / 30$, p. 180; Gentleman's Magazine, 1841, 16: 656.

${ }^{34}$ Frederic Boase, Modern English biography, Truro, Netherton and Worth, for the Author, 1892-1901, s.v. John Adams; obituary in Gentleman's Magazine, 1856, 44: 195-6.

${ }^{35}$ For the election in Warwick, see The Times, 1837, 24 Feb., 7 b, and 29 Mar., 3 c. Conolly was one of the supporters of William Collins, the opponent Whig-Radical candidate.

${ }^{36}$ For the mixed nature of Victorian ameliorists, see Philip Abrams, The origins of British sociology: 1834-1914, University Press of Chicago, 1968, pp. 31-52. 


\section{Akihito Suzuki}

Swedenborgian, and served as the chairman of the Swedenborg Society, through which he became a friend of John Flaxman and a patron of William Blake. ${ }^{37}$

The switch to the new mode of managing the asylum was swift and relentless. Immediately after Tulk joined the committee in 1838, the visiting justices deprived Ellis of the authority to appoint officers, which prompted his resignation. From the viewpoint of Ellis, what was at stake was his right as the patriarch of the institution, rather than the status of the medical profession. Ellis regarded the power of appointment as the vital part of his office. Without that power, the medical superintendent, he wrote, "gradually ceases to exert himself, and is content with kindly performing a dull routine of uninteresting duties." 38 From the magistrates' point of view, depriving the medical head of the power of appointment was a departure from the domestic government of the asylum. Shortly afterward, the medical and financial offices were separated, never to be united again. ${ }^{39}$

When in November 1838 Adams joined the committee, a sub-committee was appointed to launch a thorough reform. The committee was self-consciously reformist, probably reflecting Tulk's fresh memory of Westminster. It described its task as "an investigation of the state of the asylum, and in making such alterations and improvements in its system of government, as the condition of the establishment, and its increased number of officers and patients seemed to require." 40 When in April the next year Clitherow retired from the chairmanship and Tulk succeeded to the office, the committee had already completed several changes, besides firing both the new medical superintendent and the new steward.

The reform expressed their belief in a rigorous, de-familiarized and de-personalized bureaucracy with rigidly fixed responsibilities for each officer of the institution. ${ }^{41}$ They "established an entirely different system of control and responsibility in the steward's department": they "remodelled the general regulations for the government of all the officers of the establishment". To facilitate their grip on what was going on in the asylum, they "required all orders [by the steward] to be in writing and signed by the superintendent", and when the committee found the steward had not followed this regulation, they fired him immediately. Mr Whelan, the new steward, satisfied the committee very much, and in a year they were pleased at "the systematic regularity with which the accounts are kept." 42

This belief in bureaucratic rigour was, in fact, the very notion held by earlier critics like MacWilliam and Knight. Although they did not admit to any concessions, the new committee incorporated the pressure to rationalize and bureaucratize the management of the asylum. ${ }^{43}$ The clear definition of the duties of each officer, the exact keeping of the

\footnotetext{
${ }^{37}$ For Tulk's life, see Dictionary of national biography, London, Smith, Elder, 1908-1909 (DNB); Mary Catherine Hume, A brief sketch of the life, character, and religious opinions of Charles Augustus Tulk, London, James Speirs, 1890; Raymond H Deck, Jr, 'New light on C. A. Tulk, Blake's nineteenth-century patron', Studies in Romanticism, 1977, 16: 217-36. For his promotion of Catholic emancipation, see GLRO MJ/OC/30, p. 91; The Times, 1840, 24 July, 7 c.

${ }_{38}$ GLRO MJ/OC/29, pp. 219 and 418; Warner Ellis, op. cit., note 10 above, pp. 53-4; Ellis, op. cit.,
}

note 8 above, pp. 208-9; 'Resignation of Sir W. C. Ellis', Phrenological Journal, 1837-8, 11: 285-6.

39 GLRO MJ/OC/29, pp. 418-19.

40 GLRO MJ/OC/30, p. 171.

41 In prisons, a non-familial image of management was established from around the 1820s. See Michael Ignatieff, $A$ just measure of pain: the penitentiary in the industrial revolution 1750-1850,

Harmondsworth, Penguin, 1989, p. 178.

${ }^{42}$ GLRO MJ/OC/30, pp. 173-5 and 386.

43 The new committee did not ingratiate itself with the critics of the old regime. See GLRO MJ/OC/30, p. 386. 
account book, close recording of asylum expenditures, and so on, were all that MacWilliam had demanded. As if to refute Knight's criticism of Ellis's incorrect statistics, Conolly issued aggressively detailed and meticulous statistical tables, a procedure which was initially suggested by Adams. ${ }^{44}$

These rational and bureaucratic reforms were accompanied by benevolent and paternalist rhetoric and practice. Under Clitherow and Ellis, the major concern of the asylum was economy. Ellis managed to reduce the weekly rate per head from $9 \mathrm{~s}$. at the opening to $5 \mathrm{~s}$. $3 \mathrm{~d}$. in 1837 , by more than doubling the capacity of the asylum and by heavily appropriating the labour of the patients and attendants. ${ }^{45}$ The new committee stopped this parsimony and argued for the legitimate power of the magistrates to increase the weekly rate to $8 \mathrm{~s} .51 / 2 \mathrm{~d} .{ }^{46}$ In May 1839 , Adams's speech at the quarter sessions court overrode opposition from several parishes and persuaded the magistrates to agree to a 60 per cent increase in the weekly rate for the inmates, by contrasting the mean and cruel workhouse test of the central government with the generous and benevolent asylum of the local justices. It is almost certain that this increase in the rate led to better conditions for the inmates. ${ }^{47}$

By the time that Conolly started his job in June 1839, the Middlesex magistrates had, therefore, successfully established a new powerful model of the asylum, which combined the old and new ethos, appealed to both Tory and Whig JPs, and exorcised a gloomy prospect of humiliation by government inspection.

\section{A Psychiatrist in Slippers: Non-Restraint in the Bureaucratic Context}

Conolly turned out to be the right man in the right place. His fervent zeal for reform was ideal for the purpose, and his moderate Whiggism made him a safe choice. The magistrates and Conolly worked in perfect unison, at least on the surface. ${ }^{48}$ On his appointment, Conolly proposed to improve the diet on the basis of the increased weekly rate, and the committee's report proudly announced the increase in solid food such as meat, bread and cheese instead of the workhouse-like diet of gruel and broth. As we have seen, the committee had the idea of a new statistical arrangement, and Conolly effected it. ${ }^{49}$ The installation of the non-restraint system followed the same pattern of shared initiative between the magistrates and the doctor.

Although there was an insider conspiracy against Conolly, the magistrates were remarkable in their support of non-restraint and Conolly. ${ }^{50}$ The most prominent role was

\footnotetext{
44 GLRO MJ/OC/30, pp. 175 and 287; Conolly, op. cit., note 2 above, p. 185. For the Whig and Utilitarian aspect of the Victorian interest in statistics, see Abrams, op. cit., note 36 above, pp. 13-30; John $\mathrm{M}$ Eyler, Victorian social medicine: the ideas and methods of William Farr, Baltimore, Johns Hopkins University Press, 1979, pp. 1-36.

45 GLRO MJ/OC/27, pp. 211 and 362-3, $\mathrm{MJ} / \mathrm{OC} / 28$, pp. 101-2; MJ/OC/30, p. 174. The committee was proud that Hanwell was one of the cheapest asylums in Britain.

${ }^{46}$ GLRO MJ/OC/30, pp. 175-7. See J F Pownall, The Pauper Lunatic Asylum Act $(8 \& 9$ Vict. Cap. 126), London, William Benning, 1845, who says that
}

the decision of the Middlesex magistrates was incorporated into the amended law. Almost certainly the author was related to Henry Pownall, another active Tory member of the asylum committee.

${ }^{47}$ GLRO, MJ/OC/30, pp. 193-4; The Times, 1839 , 17 May, $6 \mathrm{c}$.

${ }^{48}$ University College London, SDUK papers, Conolly to Coates, 26 Aug. 1839, suggests that Conolly was not entirely happy.

${ }^{49}$ GLRO MJ/OC/30, p. 287; Lancet, 1839-40, i: 649.

${ }^{50}$ For the conspiracy, see Andrew Scull, Charlotte MacKenzie, and Nicholas Hervey, The transformation of the mad-doctoring trade, Princeton 
played by Adams. He initially advised Conolly to visit the Lincoln asylum under Robert Gardiner Hill and to learn how the system worked. Using the pseudonym of "A LookerOn", Adams contributed more than twenty articles to the Lancet, being by far the most prolific writer in the debate over non-restraint. That Adams was indispensable for the success of the system was admitted by Hill, Conolly, his fellow magistrates, and himself: it was reported that Adams once said "if it were not for him, that said Dr. Conolly would not be able to go on". 51

Some other magistrates were also involved in the support of the non-restraint system. With Adams, Tulk made a series of disclosures in the Lancet of a minor scandal at Bethlem, based on an interview with one of the inmates. ${ }^{52}$ This was part of the vendetta against its visiting physician Sir Alexander Morison and its governor Peter Laurie, who was also on the Hanwell Asylum committee, the two men having expressed their criticism of non-restraint. ${ }^{53}$ Under the pseudonym of "Philanthropos", one of the magistrates (possibly Thomas Hodgkin, the Dean of Carlisle) wrote a series of long articles on the plan to reform old, traditionalist, and aristocratic Bethlem after the model of the new, rationalized, and non-restraint Hanwell. Significantly, these attacks against Bethlem from Hanwell rarely failed to include reference to the insufficient statistics kept by the hospital and the lack of regulations governing its staff, the very points over which the old regime of Clitherow-Ellis had been criticized. ${ }^{54}$

Why, then, were the Middlesex magistrates so keen to defend the non-restraint system? Part of the answer lies in their sense of competition with the government. From the beginning of the new regime of Tulk and Adams, the committee wanted to make Hanwell "a model of institutions of a similar kind", and Adams was reported to have once said "the eyes of all Europe are now looking to the asylum at Hanwell." 55 These remarks suggest that they gambled for a spectacular success. A speech by Adams betrays their concern:

in as much as their county had taken the lead in the improvement of prison discipline, he was anxious that they should be the first one in one of the greatest acts of humanity that could be accomplished-the alleviation of the bodily sufferings of those unhappy [lunatics]. ${ }^{56}$

This speech reminded the local justices of two things. First they had a paternalist duty to ameliorate the sufferings of lunatics. The bodies of the lunatics should be pampered,

\footnotetext{
University Press, forthcoming; Hunter and Macalpine's introduction to Conolly, op. cit., note 1 above, pp. 25-7. See also GLRO MJ/OC/32, pp. 61-2; Hi 1/HLL/A5/1, 59th report of the visiting justices, pp. 12-15 and 20; Francis Tebbutt, Letter to the magistrates of the county of Middlesex, London, John W Parker, 1841.

${ }^{51}$ Hill, op. cit., note 2 above, pp. 17-18; Conolly, op. cit., note 2 above, p. 185; Gentleman's Magazine, 1856, 44: 195-6; Tebbutt, op. cit., note 50 above, p. 27. For Adams's role in spreading the non-restraint idea to other institutions, see Scull, et al., op. cit., note 50 above; Nicholas Hervey, 'The Lunacy Commission 1845-60', Ph.D. thesis, Bristol, 1987, pp. 365-6.

52 C A Tulk, 'The coercion system, inhuman treatment of the insane in the Bethlem Lunatic Asylum', Lancet, 1840-1, i: 296-7. This disclosure
}

seems to have ended in an anti-climax. See ibid., pp. 342-5.

${ }^{53}$ Hill, op. cit., note 2 above, p. 37; Hunter and Macalpine's introduction to Conolly, op. cit., note 1 above, p. 27. For Adams's lambasting vengeance on Morison, see Lancet, 1840-1, ii: 315-16, 447-8, $664-6,761-3$. For Laurie's opposition to nonrestraint, see Lancet, 1840-41, i: 238-41. Later Laurie explained that his opposition was due to his being a patron to Tebbutt, and seems to have repaired his relationship with the asylum committee. See The Times, 1841, 29 Oct., $7 \mathrm{~d}$.

${ }^{54}$ Philanthropos, 'The royal hospitals of Bridewell and Bethlem', Lancet, 1840-1, i: 449-50, 466-8, 513-15, 529-32, 608-10.

55 GLRO MJ/OC/30, p. 378; Tebbutt, op. cit., note 50 above, p. 29.

56 The Times, 1840, 30 Oct., 7 b. 


\section{The Politics and Ideology of Non-Restraint}

freed from the irritation of restraint. Secondly and more importantly, they were in the middle of a race against the government, and particularly the Russells, to improve prisons. Adams implied that their modified silent system in the prison and the nonrestraint system in the asylum had to be the most advanced, in order to win.

In this context of the fervent rationalization and bureaucratization of the management of the asylum, another motive of the magistrates becomes clear. The non-restraint system was understood as a rational principle which would maximize the order of an asylum, as well as a benevolent act to relieve the pain of the inmates. From the very beginning of Hill's experiment at Lincoln, the non-restraint system was conceived as the embodiment of rigorous order, regularity, and uniformity. A "properly-constructed and well-regulated Asylum" was, wrote Hill, the absolute necessity for the instalment of non-restraint. ${ }^{57}$ And once the regulations were established, they should be obeyed with the utmost rigour, with the closest inspection. Hill wrote that the resident head of the institution "must exercise an unremitting control and inspection, in order that the plan may never, under any circumstances, whatever, be deviated from, in the slightest degree." 58 Conolly shared with Hill the enthusiasm for order and regularity in a large asylum. Religious services should be given punctually, and "with great exactness". "Steady and consistent performance" of a regular organist without "any interruption or uncertainty" was highly desirable. ${ }^{59}$ Even when Conolly warned of too large an asylum, the reason he gave was most peculiar. Unlike most alienists, he did not worry about the loss of personal care: he was afraid of the possible loss of uniformity in an over-large asylum. ${ }^{60}$

To this concern with imposing rigorous order, Conolly added another: that of silence, a notion no doubt transplanted from the silent system at the Middlesex prison. He wrote: "everything should be done regularly, and everything done quietly . . . Perfect order, perfect cleanliness, and great tranquility, should prevail everywhere."61 His efforts to keep the asylum quiet were almost obsessive. On Christmas night:

the resident physician went through the wards at twelve o'clocke at night... One man was talking in No. 6, and two in No. 5 were talking in adjoining rooms . . . One of the epileptic patients laughed once. No other sound was heard. February 5 th at 11 p.m. I visited all the female wards. An old blind patient in No. 11 was drumming against the side of her bed not violently. M.P. in the same ward, noisy a few hours ago, was perfectly quiet. I think there was literally not a sound in another ward. February 6th, at 11 p.m. I visited the male infirmary and wards. Except a voice or two in No. 5 there was not a sound throughout the male side of the house. February 12th I went through all the wards on the female side of the house twice between the hours of 11 p.m. and 2 a.m. ... The silence of all the rest on the female side of the house at this hour was remarkable. ${ }^{62}$

Tulk, then involved in managing the silent-system prison, cited this extract from Conolly's journal with utmost satisfaction.

Both the justices and Conolly were, however, perfectly aware of the fundamental difference between prisoners and lunatic patients. The former should be punished and reformed (with "a just measure of pain") and the latter should be cared for. They were,

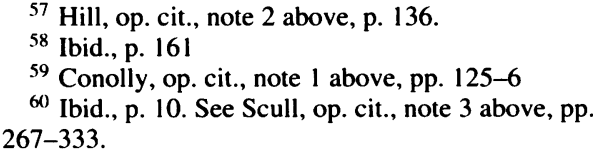

${ }^{61}$ Conolly, op. cit., note 2 above, p. 54.

${ }^{62}$ Quoted in GLRO H11/HLL/A5/1, 59th report of visiting justices, pp. 17-19. See also Conolly, op. cit., note 1 above, p. 29. 


\section{Akihito Suzuki}

nevertheless, as adamant in their belief that both prisons and asylums should be the embodiment of perfect order. The result was that the imposition of order was targeted less at the patients than at the keepers or attendants, whose vigilance was increasingly regarded as the linchpin of the success of the institution. ${ }^{63}$ The attendants' daily and weekly duties were defined in minute detail, with an elaborate system of fines if they neglected them. ${ }^{64}$ Their working timetable became more specific. Under Ellis they had been told to rise at 6.00 , to do some work, and to feed the patients breakfast at 8.00; now they must begin their duties at 6.00 , take some patients to the laundry at 6.30 , go to the kitchen at 7.00, take patients to the chapel at 7.45, and feed them breakfast in the dininghall at 8.15. ${ }^{65}$ The sick patients who could not dine with the others were by no means exceptions to this rule: the attendants were to take care that they had their breakfast in their own rooms at exactly the same time. ${ }^{66}$

This cult of work-discipline is quite understandable when one remembers that the magistrates were running silent-system prisor.s, for the success of which it was vital to ensure the vigilance of the attendants over the prisoners. ${ }^{67}$ Signs of the interconnections between the asylum staff and those of penal institutions were abundant. The muchpraised Mrs Bowden, the first matron under the non-restraint system, left the asylum for service as the matron of the convict prison in Van Diemen's land. The asylum committee borrowed from the prison committee the idea of increasing the wages to employ vigilant and highly-disciplined attendants. ${ }^{68}$

The cult of order in prison and asylum management had common roots in the infusion of the military cast of mind into the civil sphere. In the post-Napoleonic-War period, the civil service was greatly affected by a large number of officer-veterans with experience of working in a vast hierarchical and centralized organization. Military experience was particularly valued in the sphere of prison discipline, transforming eighteenth-century vulgar and corrupt gaolers into gentlemanly and rigorous prison-officers. ${ }^{69}$

Via the ideal of military precision, the old tie between lunatic asylum and prison was renewed, less as a place of physical confinement than as one that embodied high efficiency and perfect order. ${ }^{70}$ One contemporary account of the seclusion of violent patients at Hanwell was filled with military terms:

${ }^{63}$ For a detailed study of the attendants of Hanwell, see Camilla M Haw, 'John Conolly's attendants at the Hanwell Asylum', Hist. Nurs. J., 1990, 3: 26-58.

${ }^{64}$ Haw, op. cit., note 63 above, pp. 41-4.

65 Ellis, op. cit., note 8 above, pp. 342-4; GLRO H11/HLL/A5/1, 59th report of visiting justices, pp. 43-59: Conolly, op. cit., note 1 above, pp. 87-9. See also William Parry-Jones, The trade in lunacy, London, Routledge \& Kegan Paul, 1972, pp. 189-92. For the control of time in factories, prisons and schools, see Michel Foucault, Discipline and punish: the birth of the prison, Harmondsworth, Penguin, 1979; E P Thompson, 'Time, work-discipline, and industrial capitalism', Past and Present, 1967, no. 38, 36-97.

${ }^{66}$ GLRO H11/HLL/A9/1, 'Manual of the duties of the ward-attendants at the Middlesex Asylum, Hanwell (1846)'. Compare with an asylum at Avignon run by the order of the Soeurs de la charité, where meat and soup were kept warm in the kitchen night and day, so that the patients could eat whenever they wanted. 'Lunatic hospital at Avignon', Edinburgh medical and surgical Journal, 1817, 13: 407-8.

${ }^{67}$ For the opposite extreme of entirely depersonalized control in the separate system, Robin Evans, The fabrication of virtue: English prison architecture, 1750-1840, Cambridge University Press, 1982.

${ }^{68} \mathrm{GLRO} \mathrm{MJ} / \mathrm{OC} / 30$, p. 380.

${ }^{69}$ MacDonagh, op. cit., note 22 above, p. 5; Ignatieff, op. cit., note 41 above, pp. 190-1; McConville, op. cit., note 27 above, p. 245.

70 The shift from the old physical confinement and punishment to the modern intensive institutional discipline and correction has been discussed in Foucault, op. cit., note 65 above; François Ewald, 'Power without an exterior', in François Ewald (ed.), Michel Foucault, philosopher, New York, Harvester/Wheatsheaf, 1992, pp. 169-75. 


\section{The Politics and Ideology of Non-Restraint}

Each attendant is provided with a small whistle, and his instructions are, to use it in cases of emergency, and then his comrades on duty in the neighbouring wards, who are drilled into an instant obedience to the signal, bringing at once an overwhelming force to bear upon the same point, reduce the possession of the field to a mathematical certainty, . . . no manoeuvre executed under the eye of Napoleon could be more skilfully accomplished. ${ }^{71}$

Conolly seems to have been aware of the infusion of military and penal discipline into the asylum. Later he blamed the committee for introducing over-rigorous and prison-like rules for the conduct of officers and attendants. ${ }^{72}$ The attendants of Hanwell confirmed, however, that Conolly was himself a rigorous, enthusiastic and even sinister disciplinarian. His midnight visits to the wards were to keep the night attendants on their toes, as well as to watch the patients. He even ordered a special pair of soft slippers which enabled him to walk without noise, so that he could take negligent attendants by surprise. $^{73}$

Conolly's high concern for work-discipline reflected that of the magistrates. Millingen was fired precisely because of "the relaxed state of discipline" and the disorder of the asylum, and the committee congratulated Conolly for "the order and alacrity" with which officers and attendants under him performed their duties. ${ }^{74}$ Tulk's experience in the early factory movement and his Swedenborgianism might have made him model the asylum after the utopian factory of Robert Owen, who reportedly once came to see Conolly at the asylum. ${ }^{75}$ Conolly was, however, not forced to play the role of watchdog over the workforce against his will. Indeed, his middle-class background seems to have made him a relentless disciplinarian. The working man's companion. Cottage evenings, the work Conolly wrote for the Society for the Diffusion of Useful Knowledge in 1831, shows that he firmly believed that the working classes should value punctuality, frugality, and the regular life style of Benjamin Franklin. ${ }^{76}$

The demands for tight work-discipline and non-restraint were intertwined. Conolly was explicit in claiming that non-restraint was the most necessary condition to achieve a well-ordered asylum and highly disciplined attendants:

Any contrivance which diminishes the necessity for vigilance, proves hurtful to the discipline of an asylum. Physical restraints, as they rendered all vigilance nearly superfluous, caused it to fall nearly into disuse. ${ }^{77}$

Note the underlying logic here: one needs non-restraint in order to achieve tight discipline among the workforce, not the other way round. Rigorous work-discipline was by no means an undesirable price to pay for the abolition of chains on the patients; but, non-restraint was the key to the imposition of work-discipline on the workforce. In other

\footnotetext{
${ }^{71}$ Familiar views of lunacy and lunatic life: with hints on the personal care and ... management ... by the late medical superintendent of an asylum for the insane, London, John W Parker, 1850, pp. 151-2.

72 Conolly, op. cit., note 1 above, p. 138.

${ }^{73}$ Clark, op. cit., note 9 above, pp. $40-1$. This account by the attendants was given by Hitchman, who occupied the medical office at Hanwell after Conolly. For the "surprise" inspection by officers, see Haw, op. cit., note 63 above, p. 42 .

74 GLRO MJ/OC/30, pp. 179 and 379.

75 Many of Tulk's writings use the terms
}

"harmony" and "co-operation" in a conspicuous way. See GLRO MJ/OC/30, pp. 179 and 378; H11/HLL/A5/1, 54th report of the visiting justices. For Owen and Conolly, see Tebbutt, op. cit., note 50 above, p. 19.

${ }^{76}$ John Conolly, The working man's companion. Cottage evenings, London, Charles Knight, 1831. For the Mechanics' Institutes, see Steven Shapin and Barry Barnes, 'Science, nature and control: interpreting mechanics' institutes', Soc. Stud. Sci., 1977, 7: 31-74.

${ }^{77}$ GLRO H1 1/HLL/A7/1, p. 46. 


\section{Akihito Suzuki}

words, "restraint was the grand substitute for inspection, superintendence, cleanliness, and every kind attention. It was not until restraints had been for some time abolished that I ever found the inspection plates properly attended to."78

Non-restraint had, of course, the implication of liberation. Both Hill and Conolly saw in themselves the image of Pinel, smashing the chains and fetters of the ancien régime. ${ }^{79}$ A profound difference lay between the psychiatrists who thought their role was essentially that of liberation and those who regarded restraint as the key part of their job, and the present paper has not investigated that aspect of non-restraint. ${ }^{80}$ The abolition of chains and the liberation of patients were, however, not the whole story. Conolly himself explained that "the mere abolition of fetters and restraint constitutes only a part of what is properly called the non-restraint system," by which he meant "the watchful, preventive, almost parental superintendence". ${ }^{81}$

\section{"A House Full of Irritable Minds"}

Conolly was extremely successful and competent in making the asylum as orderly as possible, keeping discipline among the attendants, and running its well-organized machinery. At the same time, he found himself to be embarrassingly incompetent at providing moral treatment, the subtle face-to-face psychological manoeuvring of patients by acting on the latent rationality in their minds. ${ }^{82}$ In sharp contrast to Ellis, who was loyal to the ideal of personal and individualistic mental care, Conolly's contact with the minds of individual patients was minimal. While violent patients had provided a prime opportunity for Sir William and Lady Ellis's charismatic and parental moral control, Conolly thought it best to leave them in seclusion. ${ }^{83}$ Indeed, Conolly pathetically wrote in his first annual report, in terms which almost certainly reveal his attempts and failure:

habitual intercourse with the insane cannot but impress those the most zealous for giving extended exercise of what is termed moral treatment, with the conviction, that the only prudent course with a lunatic during a state of violence is to interfere as little as possible. Danger and mischief must, of course, be guarded against; but direct interruption is not always practicable; reasoning produces fresh irritation; contradiction commonly exasperates. ${ }^{84}$

A lot of Conolly's suggestions reflected his lack of confidence when face-to-face with a mad mind. He tended to move away from direct psychological liaison, seeking to distance himself from the mad. The opportunities for "direct mental treatment", observed Conolly, were almost nil for pauper lunatics. What one could do was "indirect mental

${ }^{78}$ Conolly, op. cit., note 1 above, p. 28.

${ }^{79}$ Hill, op. cit., note 2 above, p. 147; in one of Conolly's portraits several books appear, one of which bears the word, "Pinel".

${ }^{80}$ Ardent opposers of non-restraint include Sir Alexander Morison and John Haslam. See John Haslam, Considerations on the moral management of the insane, quoted in Vieda Skultans (ed.), Madness and morals: ideas on insanity in the nineteenth century, London, Routledge \& Kegan Paul, 1975, pp. 138-9; Society for the Improvement of the Condition of the Insane, $A$ selection of papers and prize essays on subjects connected with insanity, London, by the Society, 1850, pp. 1-5.

\footnotetext{
${ }^{81}$ Conolly, op. cit., note 2 above, p 35.

82 There are several different interpretations of moral treatment. See Michel Foucault, Histoire de la folie à l'âge classique, 2nd ed., Paris, Éditions Gallimard, 1972, pp. 483-530; Andrew Scull, 'Moral treatment reconsidered', in idem, Social order/mental disorder, London, Routledge, 1989, pp. 80-94; Roy Porter, Mind-forg'd manacles, London, Athlone Press, 1987, pp. 206-28.

${ }^{83}$ Ellis, op. cit., note 8 above, pp. 195-6; Warner

Ellis, op. cit., note 10 above, pp. 36-7.

${ }^{84}$ GLRO H11/HLL/A7/1, p. 46.
} 


\section{The Politics and Ideology of Non-Restraint}

treatment", i.e., arranging the building, hanging lithographs in the corridor, and planting shrubs in the airing court. Long conversations with the patients were "generally useless, and now and then mischievous": they should be short and limited to "occasional single remarks". 85

This fashioning of an indirect and de-personalized psychiatry was accompanied by a remoulding of the image of the patients. From the beginning, one of the basic tenets of non-restraint was that any form of mechanical restraint irritated the insane and exacerbated madness. The supporters of this view thus painted a lurid picture of a patient struggling to free himself from a strait-jacket. ${ }^{86}$ The list of the sources of irritation conceived by Conolly was endless, and he insisted that almost obsessive care should be taken not to get on the patients' nerves:

Every regulation, every action, the spirit of every remark, almost every look becomes important. The mere manner of the officers and attendants, and the deportment in passing through the wards, their tone of voice, even the mode of opening and shutting the door, may affect the sensitive organizations [of the patients]. ${ }^{87}$

The inmates at Hanwell were thus depicted as easily offended, difficult, irritable, delicate, and fragile. The slightest mis-contact would trigger exasperation and torment the wounded psyche of patients. As Conolly succinctly phrased it, the asylum was "a house full of infirm and irritable minds." 88

With the idea that both physical and psychological contacts were harmful, and with the conception of the patients as super-sensitive and hyper-irritable, the best one could do was, therefore, to keep one's distance from them, to watch over them, and to concentrate on the external circumstances-the building, the rules, the attendants, the lithographs in the wards, the shrubs in the court, the padded room for seclusion, the noiseless "inspection plate", and so on. ${ }^{89}$ In one of the lectures held at the asylum, Conolly summed it up: "the superintendence is constant, the interference only occasional." 90 In other words: watch them, but do not touch them, both in terms of their bodies and their minds. This was, of course, far from neglect. No doubt his belief in kindness was genuine and sincere. But this was kindness receding from direct contact with the patients, the kindness to create distance.

The famous observation of Henry Maudsley, Conolly's son-in-law, squares with the picture drawn above:

the actual practice of his profession was not agreeable to [Conolly]. I have often heard him say, that if his life were to come over again, he should like . . . to be at the head of a large public asylum, in order to superintend its administration. ${ }^{91}$

85 Ibid., p. 70.

${ }^{86}$ R G Hill, 'Objections to violent restraint of lunatics', Lancet, 1839-40, i: 796-7; Conolly, op. cit., note 2 above, pp. 36-9; The Times, 1842, 3 June $7 \mathrm{f}$.

87 John Conolly, 'Lecture one of clinical lectures on the principal forms of insanity', Lancet, 1845, ii: 357-9, p. 358.

${ }^{88}$ Ibid. Conolly himself was well-known for his irritability and impatience. See DNB; Munk's Roll, vol. 4; Clark, op. cit., note 9 above, p. 41, where Hitcham remembered Conolly as a "supersensitive" person, suffering from chronic itching skin diseases.

${ }^{89}$ For all these contrivances, see Conolly, op. cit., note 1 above.

90 John Conolly, 'Lecture three of the clinical lectures on the principal forms of insanity', Lancet, 1845, ii: $467-70$, p. 469.

${ }^{91}$ Maudsley, op. cit., note 19 above, p. 172. 


\section{Akihito Suzuki}

Conolly abandoned moral treatment in its original version of face-to-face and personal care: and he reduced it to the asylum administration; the arrangement of the building, organizing the everyday life of the patients, maintaining uniformity in the asylum, and exercising surveillance over the attendants (with soft slippers on).

If one remembers that the rationalization of administration and maximization of order in the asylum were the ultimate goals of the Middlesex magistrates, it is understandable why they appreciated Conolly's enthusiastic performance as manager of the asylum. Yet Conolly had been digging his own grave by retreating from moral treatment, and by overcommitting himself to keeping order in the asylum, and turning himself into a watchdog of order. The crucial point was that Conolly in effect adopted the magistrates' view that the key to a successful asylum was not the personal authority of its medical head over the patients, but the external environment constructed around them. Ellis's criticism of those who had fired him emphasized exactly this point: "[an] honourable and high-minded [resident medical superintendent] . . . will be of more avail than a code of regulations, and a regiment of visitors to put them in force." Samuel Tuke, too, observed that "it is the character of the persons engaged more than the change of system, . . . which will effectually raise the condition of our asylums."92

The spectacular "success" of Hanwell indicated to the magistrates that Ellis and Tuke were wrong: what mattered was not the personality of the medical superintendent, but designing the workings of the asylum, supervising the running of the bureaucratic machine, and replacing unfit or faulty parts. In 1844 , they found that Conolly was an unfit part, whose growing private practice could not co-exist with his duty as the resident full-time superintendent. They again took drastic measures, explaining, "in a complicated machine, no one part can be disarranged without its affecting in a greater or less degree the whole."93 Tulk, Adams and the other members of the committee now brought bureaucratization to completion: they replaced Conolly with John Godwin as the head of the establishment, under whom Conolly was expected to work. The choice of Godwin was a transparent demonstration of what the magistrates wanted: the new head was an ex-military officer and had applied for the position of prison governor. They wanted a man with "methodical habits", and they thought that in that respect a doctor could not beat a military officer: they found that "the habits of life among medical men generally are not those which best fit them to look into the domestic details of a great establishment." 94

This decision infuriated Conolly and contemporary alienists, and seems to have caused a storm of protest among the officers of the Hanwell, prompting the resignation of the chaplain (who, incidentally, then accepted a post at Pentonville), and one of the assistant physicians. Godwin resigned in less than six months, and the idea of a non-

\footnotetext{
92 Ellis, op. cit., note 8 above, pp. 209-10; Samuel Tuke, 'Introduction' to Maximilian Jacobi, On the construction and management of hospitals for the insane, trans. by John Kitching, London, John Churchill, 1841, p. xix. See also W A F Browne, What asylums were, are, and ought to be (1837), repr. with an introduction by Andrew Scull, London, Tavistock/Routledge, 1991, pp. 177-81.

93 The exact details of Conolly's resignation are
}

not clear. See Scull, op. cit., note 5 above, pp. 126-7. For the new rule, see GLRO H11/HLL/A9/1, 'Regulations for the management and government of the pauper lunatic asylum at Hanwell, Feb. 1844', p. 11.

${ }^{94}$ GLRO H11/HLLA5/2, 69th report of the visiting justices, p. 5; Statement of the services and testimonials of Captain Godwin, n.p., n.d. 


\section{The Politics and Ideology of Non-Restraint}

medical head seems to have been given up. ${ }^{95}$ The asylum committee's measure of complete bureaucratization was too extreme. At the same time, from the magistrates' viewpoint, it was entirely reasonable to conclude that the asylum head did not have to be medical, when his role was to keep its bureaucratic machine running without a single fault. An ex-military officer was an obvious choice to do that job.

\section{Conclusion}

The installation of non-restraint at the Hanwell asylum tells a story of the triumph of the lay concerns over medical ones, a process ironically assisted by Conolly himself. But this is not the entire story of non-restraint, and, the pattern found there was unlikely to have been typical of mid-century British county asylums. Both the JPs and the medical superintendent seem to have been exceptionally competent and enthusiastic. Still, what happened at Hanwell was a harbinger of what was to come. Conolly dug not only his own grave, but that of moral treatment in its original version. Late-Victorian British asylums dreamed of, and to a certain extent achieved, near-perfect order, spotless wards, regular performance of duties, well-planned timetables, and categorical and massproduced kindness of attendants. In brief, the concern shifted from the patients to the space and time in which the patients were put. The site to be acted on was neither the bodies nor the minds of the lunatics, but the asylum itself, its constitutions, its rules, its buildings, and its attendants. The Hanwell under the reformist magistrates and Conolly seems to have been the first to take a definitive step away from the patients. Moreover, the role that Conolly played at the asylum, i.e. as a mere $\operatorname{cog}$ of a huge bureaucratic machine, was to replace the earlier ideal of medical superintendent as the autocratic guiding spirit. ${ }^{96}$ It is true that non-restraint provided the English psychiatric profession with morale and self-respect. The price they paid was, however, tremendous. It cost them their medical professional status in the asylum. They were now allowed, as it were, a quiet possession of the head of the institution as a watchdog of order.

\footnotetext{
95 Conolly, op. cit., note 1 above, pp. 137-44; GLRO H11/HLL/A5/2, 71 st and 72nd reports of the visiting justices.

${ }^{9}$ Scull, op. cit., note 3 above, pp. 267-333. For another non-restraint asylum, see John Walton, 'The
}

treatment of pauper lunatics in Victorian England: the case of Lancaster Asylum, 1816-1870', in Andrew Scull (ed.), Madhouses, mad-doctors, and madmen: the social history of psychiatry in the Victorian era, London, Athlone Press, 1981, 166-97. 